\title{
Internal Auditors' Independence and Financial Performance of Listed Banks at the Nairobi Securities Exchange
}

\author{
Mburunga Elicana Mwiti, Dr. Elijah Walubuka \& Mr. Ignatius Gichana
}

${ }^{1}$ Researcher, Meru University of Science and Technology

${ }^{2}$ Senior Lecturer, School of Business and Economics, Meru University of Science and Technology

${ }^{3}$ Lecturer, School of Business and Economics, Meru University of Science and Technology

\begin{abstract}
The internal audit function plays a significant role in the financial performance of banks as it tasked with not only carrying out an oversight function but also providing assurance to their stakeholders. It is also required of an internal auditor to undertake assessment on the status of internal controls as well provide recommendations on the same albeit independently. However, these functions are adversely influenced by interference from top management leading to a significant negative impact on the financial performance of banks. Specifically this research based its investigation on the influence of internal auditors' independence on financial performance of listed banks at the Nairobi Securities Exchange (NSE). The study is pivoted on two theories; Agency Theory and Market Power Theory. This research was guided by Descriptive survey research design. The study's target population constituted of 76 Audit Managers and Internal auditors. A sample size of 76 final sampled subjects was used and respondents selected using Census sampling technique. A questionnaire was prepared and used for primary data collection from the target final sampled subjects. Descriptive statistics was employed in the analysis of quantitative data while narratives guided by themes under research were employed in the reporting of qualitative data. A Chi Sqaure was employed to test hypothesis. The research established that limited or minimal internal auditors' independence negatively influenced financial performance of listed banks at the NSE. In particular, the study established that the existence of an internal audit budget as a measure of improving internal auditors' independence influenced the financial performance of commercial banks listed in NSE. Additionally, this research established that recognized the need to enhance of Internal audit as a training ground for managers meaning most of the study's final subjects appreciated the need to gain experience prior to been promoted to an audit manager position for excellent work performance. The scholarly investigation concluded that internal audit budget that determines internal auditors' independence has a significant influence on the financial performance of listed banks. The research recommends that as a measure of enhancing internal auditor independence, commercial dependable banks listed at the Nairobi Securities Exchange (NSE) should invest financial resources in the form of a budget to their internal audit departments.
\end{abstract}

Key Terms: Internal Audit Function, Internal Controls, Internal Auditor Budget, Internal Auditors' Independence, Nairobi Securities Exchange, Financial Performance of Listed Banks

\subsection{Introduction to the Study}

Often seen as an overall monitoring activity, internal auditing is a long-standing function and an effective tool of management in many organizations and in particular in listed financial institutions as it plays a key role in fostering investor confidence and guiding their investment decisions (Holt \& DeZoort, 2009). Further, following the introduction of Sarbanes-Oxley Act (SOX) in 2000 in the U.S which provided regulations requiring listed financial institutions to employ internal auditors with accounting expertise and 
also embrace internal auditors' independence, globally research on the independence, objectivity, experience and qualifications of internal auditors has attracted the attention of several scholars (Sarens, 2009).

In a study, Burnaby and Hass (2012) reported that most listed banks in The Americas especially those in the U.S and Canada unlike in Latin America complied with internal auditing regulations requiring internal auditors' independence. Dickins and O'Reilly, (2009) reported that internal auditors' independence was important in building investor confidence in middle-market financial institutions listed in the U.S. Further, Beekes and Brown (2006) reported that financial firms listed in the Australian Stock Exchange that had adopted corporate governance characterized by both internal auditors' independence posted better financial performance than those that were management and rejected internal auditors' ethical decisions. Van Peursem, (2005) reported that internal auditors' independence that more qualified and experienced auditors enjoyed was critical in quality internal auditing of the financial position of listed banks.

In Greece, Karagiorgos, Drogalas and Dimou (2008) demonstrated that internal auditor's independence was particularly important for successful internal control of banks and their overall financial performance. In Romania, Dumitrascu and Savulescu (2012) also reported that listed banks that had adopted internal auditors' independence under corporate governance performed better in Bucharest Stocks Exchange (BVB). In Italy, Gabriella and Michela (2010) reported that listed banks were complying with regulations that require these banks to embrace internal auditors' independence.

In Bangladesh, Sultana and Haque (2011) reported that listed banks in the Dhaka Stocks Exchange (DSE) performed better financially after adopting corporate governance whose inherent requirements were internal auditors' independence. In Jordan, Al Matarneh (2011) noted that internal auditors' independence which was determined by corporate governance structure did affect the quality of financial reports consequently influencing the financial performance of these banks. Uyar and Kilic (2012) did report that internal auditors' independence was critical in the decision making process of whether to disclose financial ratios of Turkish banks listed in the Borsa Istanbul (BIST).

The importance of internal auditors in providing useful information for investors' decision-making process is also emphasized through studies in Africa. In a study in Nigeria Adeyemi and Okpala (2011) reported that internal auditors' independence was important for accurate financial reporting. In Kenya, Ondieki (2013) reported that the independence of the internal auditor was positively correlated with the financial performance of commercial banks in Kenya

\subsection{Statement of the Problem}

Internal auditors play key roles in risk assessment, evaluating assurance and internal controls of financial institutions and in particular ensuring that the quality of audit reports reflect the correct return on investment (ROI), return on equity (ROE) and return on assets (ROA) of these firms (Rossiter, 2007). They are also required to provide financial statements that would inspire investors' confidence in the company's financial performance which will thereafter assist them in future decision-making with regards to investment in the company (Mugwe, 2012). These roles are however adversely influenced by a multiplicity of organizational factors such as the interference by senior management on internal auditors' work in the form of earnings management and the professional competency of the internal auditors both of which in most cases lead to both poor loans loss provisions reporting and inaccurate accrual earnings quality information (Sarens \& De Beelde, 2006).All these is thought to dampen investors' confidence in the share value of listed banks emanating from low share prices, consequently affecting the profitability and the financial performance of these quoted banks (Ashbaugh-Skaife, Collins, Kinney \& LaFond, 2009).

Several studies have been conducted on the role of internal auditing and the performance of firms but none has been but none done on internal auditing and financial performance of banks listed in the NSE. For Example, a study by Nankunda, (2013) reported on internal auditing and the financial performance of National Water and Sewerage Corporation in Kenya but did not focus on listed commercial banks; the study by Mbuti, (2014) looked at internal auditing in SACCOs and not in listed banks and that by Kiema, (2015) looked at the relationship between internal auditors' independence and the financial performance of SMEs. This study therefore seeks to fill the gap in literature by investigating the influence of internal auditors on the financial performance of banks listed in the Nairobi Securities Exchange (NSE). Specifically it seeks to investigate the influence of; internal auditors' independence, internal auditors' qualifications and internal auditors' experience and their correlation to the financial performance of banks listed in the NSE. 


\subsection{Research Hypothesis}

$\mathbf{H}_{\mathbf{0}}$ : Internal Auditors independence does not have a significant relationship with financial performance of listed banks at NSE.

$\mathbf{H}_{1}$ : Internal Auditors independence has a significant relationship with financial performance of listed banks at NSE.

\subsection{Literature Review}

\section{Internal Auditors Independence and Financial Performance of Listed Banks at NSE}

According to Stewart and Subramaniam, (2010) internal auditors' independence and objectivity can adversely be affected by self review, close relationship with management and or audit committee and social pressure from management and or audit committees. They further find a significant correlation between internal auditors' independence and financial performance in terms of audit quality which is related to the consulting and assurance activities of internal auditors (Stewart \& Subramaniam, 2010). In their study Kiridaran, Gopal and Gerald (2010) on Auditor's independence in the banking industry demonstrated a positive relationship between limited internal auditors' independence in small listed banks in the U.S and the presence of greater earnings management in relation to under-provisioning of loan loss provisions (LLP). By employing an observational study research design and a sample of 63 , they further demonstrated that this non-existence of independence did result economic interests and familiarity. This they argued adversely affected the assurance activities of internal auditors resulting to poor share value performance of these listed banks and consequently their profitability (Kiridaran, et al., 2010).

Similarly, Felício, Ivashkovskaya, Rodrigues and Stepanova (2014) in their study on corporate governance and performance of listed banks in Europe established a significant positive correlation between internal auditors' independence embedded in corporate governance of listed European banks and their financial performance. Using an observational study research design and a sample of 404, they further demonstrated that in those listed banks where internal auditors' independence was threatened by Chief Executive Officer's (CEO) duality through full involvement in the audit plan, interfering with audit budgets and earnings management, these banks posted low profits especially in times of high securities' markets volatility (Felício et al., 2014). Similar findings were demonstrated by Kershaw, (2006) in a study on internal audit in who found a significantly positive relation between internal auditors' acquiesce to the demands of bank managers to agree with debatable, misleading and inaccurate accounting reports and the performance of listed banks in the U.K. He further noted that the continued costs of compromising internal auditors' independence exhibited through meeting the economic interests of internal auditors had resulted to unmanageable wastage in banks and this had a significant relation to the number of investors attracted to a listed bank stock which in turn negatively affected their financial performance indicated by investor ratios (Kershaw, 2006).

Socol, (2011) in his study on internal banking control and audit among Romanian banks found evidence that internal auditors' independence was positively correlated with the share performance of listed banks in the country. While using an observational study research design a he notes this was established through corporate governance which created an environment of non-interference of internal auditors' work by senior management and consequently improving the image of listed banks. He further argued that this improved image also exhibited a positive relationship with investor confidence leading to improved share value and profitability (Socol, 2011). However, Karmanova (2013) in a Lithuanian study on internal audit of listed commercial banks found no significant relation between internal auditors' independence and financial performance noting that commercial banks' auditor committees' interfered with the Chief Internal Auditors' (CIA) annual audit plans. Using a historical design and a sample of 7 listed commercial banks she however argued had no significance influence on the share price of the listed Lithuanian commercial banks and consequently the financial performance (Karmanova, 2013).

Further, Htay, Ab Rashid, Adnan and Meera (2011), in a study on internal auditors' independence and their effective evaluation of risk management in banks found a positive correlation between these and the financial performance of listed banks. Using an observational study research design and a sample of 102 observations, they assert this relationship was also exhibited in the integrity of financial reports reflected by reliable earnings quality. Further, they demonstrated that this independence was extended to external auditors thereby reducing fees that would have been charged for the purchase of non-auditing services (NAS) by the external auditor which in-turn improved return on assets and profitability of the listed banks that attracted investors (Htay et al., 2011). Similarly, Basiru and Nur Ashikin (2015) in a study focused on 
listed banks in Malaysia observed a significantly positive correlation between financial performance and internal auditors' independence. Making use of an observational study research design and a sample of 37 they further contend this arose from the ability of the internal auditors to effectively monitor management and in the process reduce chances of self gain activities indicated by the profitability of these institutions (Basiru \& Nur Ashikin, 2015).

Further, Güneş and Atılgan (2016) in a comparative study on effectiveness of audit committees in terms of independence of internal auditors found evidence that audit committees were more effective in listed banks in the U.K and upheld more internal auditors' independence than in listed Turkish banks. By employing a cross-sectional design and a sample of 20 listed banks they however noted that in listed Turkish banks, internal auditors' independence had an insignificant negative relationship with both the return on assets and return on equity and was therefore not related to their financial performance (Güneş \& Atılgan 2016). Additionally, Alzeban (2015) in a study on influence of Audit Committee also found evidence that its characteristics such as creating an enabling environment that would uphold internal auditors' independence did lead to integrity and objectivity among internal auditors in reporting the financial position of listed financial firms Saudi Arabia. Using a descriptive survey design and a sample of 74, he however asserts that due to low levels of interest on audit information by its consumers, there was no significant relationship between internal auditors' independence, and the share value of firms listed in the Saudi Stock Exchange (Alzeban, 2015). However, Awdat (2015) in a study on the impact of upholding internal auditors' independence in listed banks in Jordan postulated that shareholders valued commercial banks that did this than those that didn't. Further, making use of a descriptive survey design and a sample of 65 internal auditors he demonstrated a strong positive association between internal auditors' independence and return on equity ROE) exhibited through the attraction of new investors improving the share price of commercial banks leading to profitability and better financial performance (Awdat, 2015). These findings were however disputed by another study which noted that though the independence of internal auditors was important for the effective and efficient risk management process, there was a negative association between it and the ROE and ROA of listed banks in Jordan (Modar \& Shatha, 2015).

Similarly, Ibrahim (2011) in a study on found evidence that internal auditors' experienced low levels of independence from senior management in performing their duties in listed financial firms in Egypt. Using an exploratory research design he further demonstrated that this did lead to high levels of earnings management that negatively influenced investors' confidence and was positively correlated to return on equity and the share value of listed banks leading to low profitability of these banks (Ibrahim, 2011). Further, Alaswad and Stanišić (2016) in a study using Return on Assets (ROA) as a performance indicator, found a significant correlation between internal auditors' independence and the financial performance of listed financial organizations. Using an observational study research design and a sample of 78 observations he demonstrated that listed financial organizations that had adopted internal auditors' independence had their shares performing better than those that had low organizational independence in the Libyan Stock Market. This they argued was because internal auditors' independence did lead to lower economic interest on the part of the internal auditors and reduced familiarity resulting to effectiveness that contributed to improved financial reporting thereby inspiring investor confidence leading to profitability (Alaswad \& Stanišić, 2016). Ishaya, Sieh and Akanet (2013) in their study on internal governance mechanisms also found evidence that the independence of internal auditors' working for listed deposit taking banks in Nigeria was key in providing a systematic, regimented approach to evaluate and improve the effectiveness of risk management, control, and governance processes. Adopting a correlation research design and sample size of 14 they further noted that this was important for attracting investors as it affected the return on assets (ROA) and had a significant positive relationship with the share value reflected in the financial performance of these listed banks (Ishaya, et al., 2013). However, Dauda (2015) in a study on effectiveness audit committees in espousing internal auditors' independence found no significant relation between internal auditors' independence embraced by audit committees and the share value of listed deposit taking banks in Nigeria. Using a descriptive survey design and 55 respondents from 5 sampled banks he attributed this to the existing lack of interest on and understanding of audit information by its consumers such as shareholders (Dauda, 2015).

In contrast, Darko, Ali Aribi and Uzonwanne (2016) in their study on corporate governance in listed banks, found evidence that internal auditors' independence established through corporate governance had a positive association with the share value of listed banks in Ghana. Additionally, making use of a cross-sectional 
design and a sample of 20 they established that an accommodative ownership structure that embraced audit committee independence did contribute to internal auditors' effectiveness leading to improved audit quality. It is through this they further contend that listed banks signaled to the Ghana Stock Exchange on effective internal control which in turn inspired investors leading to improved share value and profitability (Darko, et al., 2016).

\subsection{Theoretical Perspective}

This study is anchored on two theories: Agency Theory and Market Power Theory.

\subsubsection{Agency Theory}

Formulated by Adams, (1994) agency theory is based on a premise that there exists an information asymmetry between the principals' and agent. This he notes has negative effects on the ability of the principals to effectively monitor if their interests are being served by agents (Adams, 1994). However, Nicholson and Kiel (2007) contend that agency theory attempts to align the interests of a firm's principal to those of its managers. It is based on the assumption that there is an inherent conflict between the interests of a firm's owners and its management further noting that managers now possess superior knowledge and expertise to the firm's owners and are therefore in a position to pursue self-interested action at the expense of shareholders (Nicholson \& Kiel, 2007).

Further, Nikkinen and Sahlström (2004) contends to deal with the agent's tendency to self-interest and given that listed banks owners don't have full control over what accounting information system is being applied and what will be reported, internal auditors are employed to increase financial reporting and disclosures that would assist in reducing information asymmetry between listed banks owners, management and shareholders but to also improve financial reporting quality.

In linking this theory to the study, the researcher sought to unpack the effect of internal auditors' independence on financial performance of listed banks at the NSE. Specifically internal audit in listed banks is an adjunct of the function performed by external audit created by senior managers to satisfy the demands for accountability made by external participants, especially shareholders (Sherer \& Kent, 1983). The focus of internal auditors in listed banks will in this case be geared towards financial audit, fraud prevention and internal control compliance work rather than operational reviews and management audits. This therefore means that internal auditors may be inextricably bound to the interests of shareholders and managers, for example through employee share ownership schemes. Arguably this shared interest lowers internal auditing independence and also affects the nature and scope of internal auditing activities (Watts, 1988).

\subsubsection{Market Power Theory}

Developed by Bain (1951) the Market Power Theory is based on two premises the Structure Conduct Performance (SCP) and the Relative Market Power (RMP). The SCP bases its argument on how the structure of the bank it terms of its conduct and market structure influences its financial performance (Bain, 1951). Internal auditors conduct has been found to inform bank profitability (Ondieki, 2013; Kaneza, 2016). On the other hand, the RMP premise bases its argument on bank profitability emanating from the capability of these financial institutions being able to acquire a larger market share as a result of effective management that addresses the needs of internal control (Bain, 1956; Seelanatha, 2010).

This scholarly investigation adopts Market Power Theory to argue that, in order to enhance the financial performance of listed banks in terms of; Return on Investments (ROI), Return on Assets (ROA) and Return on Equity (ROE) there is need to improve on firm conduct (Onuonga, 2014). This is mainly on internal controls that relate to internal auditors independence (Kaneza, 2016).

\subsection{Research Methodology}

The study employed descriptive survey research design to carry out an investigation on the relationship between internal auditors' independence and financial performance of listed banks at Nairobi Securities Exchange (NSE). Descriptive survey research design was instrumental in facilitating the collection of qualitative as well as quantitative data on the correlation between internal auditors' independence and financial performance of listed banks at NSE. Further, survey design was also very instrumental in establishing the link between study variables and problem under investigation. This was drawn from its inherent features which provided the researcher with the opportunity to examine final sampled subjects' 
understanding and opinions concerning the problem under research. Target population 76 Audit Managers and Internal Auditors working for listed banks and Sample Size of 76 was used because the population was small. Respondents were selected making use of census sampling approach. Questionnaires administered in person were used in the collection of primary data from sampled respondents. Primary data collected was edited, examined for integrity and finally coded. Statistical Package for Social Sciences (SPSS) version 20.0 was used for descriptive statistics in the analysis of quantitative data. Valid inference on the topic of study was arrived at by presenting the investigation's findings in frequency and percentage tables. Content analysis involving the categorization of data into themes, patterns and sub-topics anchored on study hypothesis was used in the analysis of qualitative data.

\subsection{Findings and Interpretations}

The study sought to determine the effect of internal auditors' independence on financial performance of listed banks at Nairobi Securities Exchange (NSE). Findings of the same are presented in the following sections;

\section{Internal Auditors' Independence and Financial Performance of Listed Banks}

This sub section investigated the influence of internal auditors' independence on the financial performance of listed banks.

The study attempted to substantiate the extent to which final sampled subjects concurred with the following diverse on the extent to which components of internal auditors' independence influence the financial performance of listed commercial banks in Nairobi Stock Exchange (NSE). Results are presented in Table 1.

Table 1: Internal Auditors' Independence and Financial Performance of Listed Banks

\begin{tabular}{|l|l|l|}
\hline Statement & Mean & Std. Deviation \\
\hline Internal audit budget & 4.2131 & 0.60868 \\
\hline Existence of internal audit charter & 3.6066 & 1.12958 \\
\hline Internal audit annual plan & 3.082 & 0.6136 \\
\hline Internal audit as a training ground for managers & 4.1967 & 0.81281 \\
\hline
\end{tabular}

The respondents agreed that Internal audit budget (mean=4.213), Internal audit as a training ground for managers (mean= 4.1967) and Existence of internal audit charter (mean=3.6066) greatly influence the financial performance of commercial banks listed in Nairobi Securities Exchange (NSE). The respondents also indicated that Internal audit annual plan (mean=3.082) influenced the financial performance of commercial banks listed in NSE. This study findings were significant as it means that a vast majority of respondents mean of 4.213 linked the existence of an internal audit budget to the financial performance of commercial banks listed in NSE which means majority of them were of the opinion that their work needed financial resources for them to work efficiently so as to meet expected results, most of the respondents mean of 4.1967 also recognized the need to enhance of Internal audit as a training ground for managers meaning most of the study's final subjects appreciated the need to gain experience prior to been promoted to an audit manager position for excellent work performance, while a significant number of respondents a mean of 3.6066 advocated for the existence of internal audit charter as important measure of improving expertise and technocrat in the audit process thereby enhance financial performance of commercial banks listed in NSE and a sizeable number of respondents mean of 3.082 assigned great importance to Internal audit annual plan as ways of improving the financial performance of commercial banks listed in NSE. One could infer this is because employees in the audit departments of commercial banks understood the immediate needs of formulating a plan that would inform how the internal audit process should be carried out hence positively influencing financial performance of commercial banks.

The respondents suggested that there was need to not only come up with internal audit charter but as well develop effective communication strategies for its implementation to facilitate internal auditors' independence and improve financial performance of listed commercial banks. They also recommended that there was need to adopt sufficient internal audit budgets that prevent financial reliance on other departments that would interfere with its independence.

Chi-Square Test on Internal Auditors' Independence and Financial Performance of Listed Banks 
The researcher also used Pearson's chi square to test the influence of internal auditors' independence on the financial performance of commercial banks listed in Nairobi Securities Exchange (NSE). According to the findings in Table 2: the significance figure was 0.047, which shows that there was a statistically significance relationship between internal auditors' independence and financial performance of listed banks. This is because the significance figure was less than 0.05. This shows that there was evidence against the null hypothesis, a conclusion can therefore be drawn that internal auditors' independence exerts significant influence on the financial performance of listed banks.

Table 2: Chi-Square Tests on Internal Auditors' Independence and Financial Performance of Listed Commercial Banks

\begin{tabular}{|l|c|c|c|}
\hline & Value & df & Asymp. Sig. (2-sided) \\
\hline Pearson Chi-Square & 33.8794 (a) & 89 & .047 \\
\hline Likelihood Ratio & 32.563 & 89 & .004 \\
\hline Linear-by-Linear Association & 6.761 & 1 & .002 \\
\hline N of Valid Cases & 63 & & \\
\hline
\end{tabular}

\section{Financial Performance of Listed Banks}

Further, the research study attempted to determine measures of financial performance of listed banks. Respondents were therefore requested to highlight on indicators they concurred with as measures of financial performance of listed banks. Results are presented in Table 3

Table 3: Statements Related to Financial Performance of Listed Banks

\begin{tabular}{|l|l|l|}
\hline Statement & Mean & Standard Deviation \\
\hline Return on Investments & 4.112 & 0.709 \\
\hline Return on Assets & 4.482 & 0.997 \\
\hline Return on Equity & 4.266 & 0.735 \\
\hline
\end{tabular}

The respondents agreed that Return on Assets (ROA) as demonstrated by mean of 4.482 was to a very great extent a significant measure of financial performance of listed banks. Further, study final subjects agreed that Return on Equity (ROE) as shown by mean of 4.266 was to a great extent a significant measure of financial performance of listed banks. Additionally, respondents agreed that Return on Investments (ROI) as illustrated by mean of 4.112 was to a moderate extent a significant measure of financial performance of listed banks. From these study findings, one could deduce that commercial banks' employees from internal audit departments place great significance to ROA as a measure of financial performance of listed banks.

\section{Pearson's Product Moment Correlation}

A Pearson's Product Moment Correlation was conducted to establish the strength of the relationship between the variables. The findings are presented in Table 4. 


\begin{tabular}{|c|c|c|c|c|c|}
\hline & & 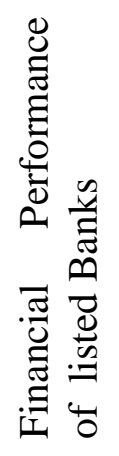 & 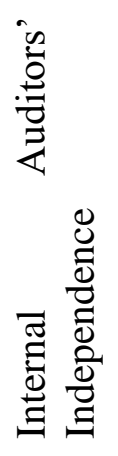 & 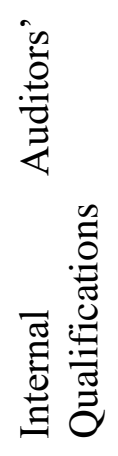 & 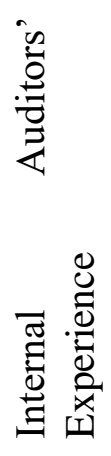 \\
\hline \multirow{2}{*}{$\begin{array}{l}\text { Financial Performance of } \\
\text { Listed Banks }\end{array}$} & Pearson Correlation & 1 & & & \\
\hline & Sig. (2-tailed) & . & & & \\
\hline \multirow{2}{*}{$\begin{array}{ll}\text { Internal } & \text { Auditors' } \\
\text { independence } & \\
\end{array}$} & Pearson Correlation & .806 & 1 & & \\
\hline & Sig. (2-tailed) & .029 & . & & \\
\hline \multirow{2}{*}{$\begin{array}{ll}\text { Internal } & \text { Auditors' } \\
\text { Qualifications } & \\
\end{array}$} & Pearson Correlation & .606 & .742 & 1 & \\
\hline & Sig. (2-tailed) & .028 & .013 & $\cdot$ & \\
\hline \multirow{2}{*}{$\begin{array}{ll}\text { Internal } & \text { Auditors' } \\
\text { Experience } & \end{array}$} & Pearson Correlation & .881 & .543 & .521 & 1 \\
\hline & Sig. (2-tailed) & .056 & .008 & .016 & \\
\hline
\end{tabular}

Results in Table 4.11 reveal that there is a strong, positive and significant correlation between internal auditors' independence and financial performance of listed banks $(\mathrm{r}=0.806, \mathrm{p}$ value $=0.029)$. In addition, the study reveals that the correlation between internal auditors' independence and financial performance of listed banks is positive and significant $(r=0.606$, $p$ value $=0.028)$. Finally the study establishes that there was a very strong, positive and significant correlation between internal auditors' and financial performance of listed banks $(\mathrm{r}=0.881, \mathrm{p}$ value=0.056). This implies that all the variables had a positive and significant correlation with financial performance of listed banks at the Nairobi Securities Exchange (NSE).

\section{Conclusions}

The study concluded that, internal audit budget has a significant influence on the financial performance of listed banks as it acted as a major platform for exercising of independence for internal auditors. It was also concluded that internal audit as a training ground for managers influenced financial performance of listed banks as they need to gain experience prior to been promoted to an audit manager position for excellent work performance. The study also concluded, existence of internal audit charter was pivotal to improving expertise and technocrat among listed banks' internal auditors.

\section{Study Recommendations}

Based on the research findings, the study recommends that to improve on financial performance commercial banks listed at the Nairobi Securities Exchange (NSE), these financial institutions should invest more financial resources to their internal audit department as a measure of enhancing internal auditors' independence.

\section{References}

[1] Adams, M.B. (1994). Agency Theory and Internal Audit. Managerial Auditing Journal, Volume 9(8), pp.8-12.

[2] Adeyemi, S.B. \& Okpala, O. (2011). The impact of audit independence in financial reporting: Evidence from Nigeria. Business \& Managemnt Review Volume 1(4), pp.09-25.

[3] Al Matarneh, G.F. (2011). Factors determining the internal audit quality in banks: Empirical Evidence from Jordan. International Research Journal of Finance and Economics, 73, pp.99-108.

[4] Alaswad, S.A.M \& Stanišić, M. (2016). Role of internal audit in performance of Libyan financial organizations. International Journal of Applied Research Volume 2(2), pp.352-356.

[5] Alzeban, A. (2015). Influence of audit committees on internal audit conformance with internal audit standards. Managerial Auditing Journal, Volume, 30(6/7), pp.539-559. 
[6] Ashbaugh-Skaife, H., Collins, D.W., \& LaFond, R.(2009). The effect of SOX internal control deficiencies on firm risk and cost of equity. Journal of Accounting Research, Volume 47 (1), pp.1-43.

[7] Awdat, A. A. (2015). The impact of the internal audit function to improve the financial performance of commercial banks in Jordan.Research Journal of Finance and Accounting. Volume 6 (3), pp.217225.

[8] Bain, J. (1951). Relation of Profit Rate to Concentration: American Manufacturing, 1936-1940. Quarterly Journal of Economics, Volume 65(3), pp.293-324.

[9] Bain, J. (1956). Barriers to New Competition. Harvard University Press, Cambridge, MA.

[10] Basiru, S.K., \& Nur Ashikin, M.S. (2015). "Audit committee attributes and firm performance: evidence from Malaysian finance companies",. Asian Review of Accounting, Volume 23 (3),pp.206231.

[11] Beekes, W., \& Brown, P. (2006). Do Better-Governed Australian Firms Make More Informative Disclosures?. Journal of Business Finance \& Accounting, Volume 33(3-4), pp.422-450.

[12] Burnaby, P.A., \& Hass, S. (2012). Internal auditing in the Americas. Managerial auditing journal, Volume 26(8),pp.734-756.

[13] Darko, J., Ali Aribi, Z. \& Uzonwanne, G.C. (2016). "Corporate governance: the impact of director and board structure, ownership structure and corporate control on the performance of listed companies on the Ghana stock exchange",. Corporate Governance, Volume 16(2), pp.259-277.

[14] Dauda, I.A. (2015). Effectiveness of Audit Committee Practices And The Value of Listed Deposit Money Banks In Nigeria. European Journal of Accounting Auditing and Finance Research Volume 3(6), pp.80-90.

[15] Dickins, D. \& O’Reilly, D. (2009). "The qualifications and independence of internal auditors". Ed. Internal Auditing, Volume 24(3), pp.14-21.

[16] Dumitrascu, M. \& Savulescu, I. (2012). Internal Control and the Impact on Corporate Governance, in Romanian Listed Companies.Journal of Eastern Europe Research in Business \& Economics. Volume 2012, 10 Pages.

[17] Felício, J. A., Ivashkovskaya, I., Rodrigues, R., \& Stepanova, A. (2014). Corporate governance and performance in the largest European listed banks during the financial crisis. Innovar, Volume 24(53), pp.83-98.

[18] Gabriella, O. \& Michella, M. (2010). "The control system in the Italian banking sector: recent changes in the application of Legislative Decree No. 231 of June 8, 2001",. Journal of Investment Compliance, Volume 11(2),pp.16-22.

[19] Güneş, N., \& Atılgan, M. S. (2016). Comparison of the Effectiveness of Audit Committees in the UK and Turkish Banks.International Journal of Financial Research Volume 7(2),pp.18-29.

[20] Holt, T.P., \& DeZoort, T. (2009). The effects of internal audit report disclosure on investor confidence and investment decisions. International Journal of Auditing, Volume13 (1),pp.61-77.

[21] Htay, S.N.N., Rashid, H.M.A., Adnan, M.A., \& Meera, A.K.M (2011). "Corporate governance and risk management information disclosure in Malaysian listed banks: panel data analysis",.International Review of Business Research Papers, Volume7(4), pp.159-176.

[22] Ibrahim, El-Sayed., E. (2011). "Internal audit function: an exploratory study from Egyptian listed firms",. International Journal of Law and Management, Volume 53(2), pp.108-128.

[23] Ishaya, L.C., Sieh, F.Y.Jnr, \& Akanet, S. (2013). Impact of Internal Governance Mechanisms On Corporate Performance In Deposit Money Banks In Nigeria. International Journal of Arts and Commerce Volume 2(8), pp.35-46.

[24] Kaneza, C. (2016). Factors Affecting the Financial Performance Of Commercial Banks Listed On the Nairobi Securities Exchange. Unpublished Doctoral dissertation, United States International University-Africa.

[25] Karagiorgos, T., Drogalas, G. \& Dimou, A. (2008). "Effectiveness of internal control system in the Greek Bank Sector",. The Southeuropean Review of Business Finance \& Accounting, Volume 6(2),

[26] Karmanova, K. (2013). Internal audit in Lithuanian commercial banks:an important part of corporate governance or just another department? Unpublished, Master in Accounting, Auditing and Analysis, Department of Business Studies, Uppsala University, pp.4-35. 
[27] Kershaw, D. (2006). Waiting for Enron: The Unstable Equilibrium of Auditor Independence Regulation. Journal of Law and Society, Volume 33(3), pp.388-420.

[28] Kiema, H.M. (2015). Influence Of Internal Audit Independence On The Financial Performance of Small And Medium Enterprises: A Case of The Construction Industry In Mombasa County, Kenya. Unpublished Research Project for Master of Business Administration Degree, Technical University of Mombasa, pp.1-77.

[29] Kiridaran, K., Gopal, V.K. \& Gerald, J.L. (2010). An Empirical Analysis of Auditor Independence in the Banking Industry. The Accounting Review, Volume 85(6), pp.2011-2046.

[30] Mbuti., E.M. (2014). Effects of Internal Audit Reporting on Financial Performance of Saccos. Upublished Doctoral Dissertation, KCA University.

[31] Modar, A., \& Shatha, K., (2015). "The role of internal auditing in risk management:evidence from banks in Jordan",.Journal of Economic and Administrative Sciences, Volume 31(1), pp.30-50.

[32] Mugwe, M.N. (2012). The Relationship Between The Independence And Objectivity of The Internal Audit Function And Earnings Per Share (Eps) In Companies Listed In NSE. Unpublished Master Of Business Administration (Mba), School of Business, University of Nairobi, pp.1-66.

[33] Nankunda, S. (2013). Internal Audit Function And Financial Performance of Public Sector Organizations: A Case of National Water And Sewerage Corporation- Mbarara Branch. Unpublished Research Report For Bachelor'sdegree In Business Administration,Bishop Stuart University, pp.298.

[34] Nicholson, G.J. \& Kiel, G.C. (2007). Can directors impact performance: A case based test of three theories of corporate governance. Corporate Governance: An International Review, Volume 15, pp.585-608.

[35] Nikkinen, J. \& Sahlström, P. (2004). Does agency theory provide a general framework for audit pricing? International Journal of Auditing Volume 8(3), pp.253-262.

[36] Ondieki, N.M. (2013 ). Effect of Internal Audit On Financial Performance of Commercial Banks In Kenya. Unpublished Research Project, Master of Science In Finance, University of Nairobi , pp.163.

[37] Onuonga, S.M. (2014). The Analysis of Profitability of Kenya`s Top Six Commercial Banks: Internal Factor Analysis. American International Journal of Social Science, Volume 3(5), pp.94-103.

[38] Rossiter, C. (2007). Top 10 priorities for internal audit in a changing environment.Bank Accounting \& Finance, Boston, Volume 20(5), pp.34-35.

[39] Sarens, G. (2009). Internal auditing research:Where are we going? Editorial.International Journal of Auditing, Volume 13(1), pp.1-7.

[40] Sarens, G. \& De Beedle, I. (2006). The Relationship Between Internal Audit and senior management:A qualitative analysis of expectations and perceptions. International Journal of Auditing, Volume 10(3), pp.219-241.

[41] Seelanatha, L. (2010). Market structure, efficiency and performance of banking industry in Sri Lanka. Banks and Bank Systems, Volume 5(1), pp.20-31.

[42] Sherer, M. \& Kent, D. (1983). Auditing and Accountability, London: Pitman.

[43] Socol, A. (2011). Internal Banking Control and Audit: A Comparative Approach in the Romanian Banking Sector.Annales Universitatis Apulensis:Series Oeconomica, Volume 13 (2),396.

[44] Stewart, J. \& Subramaniam, N. (2010). "Internal audit independence and objectivity: emerging research opportunities",. Managerial Auditing Journal, Volume. 25(4), pp.328-360.

[45] Sultana, R., \& Haque, M.E. (2011). Evaluation of Internal Control Structure: Evidence from Six Listed Banks in Bangladesh,. ASA University Review, Volume 5(1), pp.69-81.

[46] Uyar, A. \& Kilic, M. (2012). "The Influence of firm characteristics on disclosure of financial ratios in annual reports of Turkish listed in the Istanbul stock exchange". International Journal of Accounting, Auditing and Performance Evaluation, Volume 8(2), pp.137-156.

[47] Van Peursem, K. A. (2005). Conversations with internal auditors: The power of ambiguity. . Managerial Auditing Journal, Volume 20(5),pp.489-512.

[48] Watts, R.L. (1988). Discussion of financial reporting standards, agency costs, and shareholder intervention,. Journal of Accounting Literature, Volume 7, pp.125-132. 